\title{
Right video-assisted thoracoscopy thoracic duct ligation as treatment for a case of chyloptysis
}

\author{
Robert B. Xu, MBBS, Gareth Crouch, MBBS, Craig Jurisevic, FRACS, and Robert G. Stuklis, FRACS, \\ Adelaide, Australia
}

We describe a case of chyloptysis as a consequence of thoracic duct injury after aortic arch surgery and its subsequent management.

\section{CLINICAL SUMMARY}

A 71-year-old man presented with ongoing expectoration of milky, foul-tasting sputum, while denying any systemic symptoms. He first presented in 2007 with a type B dissection with an aneurysmal complex. He underwent distal aortic arch repair via a left anterolateral thoracotomy approach with femoral-femoral bypass via percutaneous cannulas. The distal aortic arch was transected and a 26-mm Dacron graft was sutured, with a distal anastomosis formed below the pulmonary hilum to the distal descending thoracic aorta. The left subclavian artery was resected as high as possible, anastomosed to an 18-mm Gelseal (Terumo Cardiovascular Systems Corp, Ann Arbor, Mich) graft that was then attached to the aortic graft. The patient was returned to the operating room postoperatively for evacuation of a hematoma, after which he progressed well and was transferred out of the intensive care unit.

On day 14, a progressive left pleural effusion was confirmed on computed tomography and tapped using needle thoracostomy. Biochemistry of the specimen confirmed a diagnosis of chylothorax, with a protein level of $22 \mathrm{~g} / \mathrm{L}$, an LD level of $530 \mathrm{U} / \mathrm{L}$, and a triglyceride level of $8.3 \mathrm{mmol} / \mathrm{L}$, meeting the diagnostic criteria determined by the Mayo Clinic $(>1.24 \mathrm{mmol} / \mathrm{L}$ or $110 \mathrm{mg} / \mathrm{dL}){ }^{1}$

After a trial of conservative therapy, including tube thoracostomy drainage and 2 weeks of a medium chaintriglyceride diet with octreotide adjunct, the chyle leak persisted and the patient received surgical intervention via redo thoracotomy.

From the Darcy Sutherland Cardiothoracic Surgical Unit, Royal Adelaide Hospital, North Terrace, Adelaide, South Australia, Australia.

Disclosures: Authors have nothing to disclose with regard to commercial support.

Received for publication Nov 19, 2012; revisions received Feb 3, 2013; accepted for publication Feb 13, 2013; available ahead of print March 13, 2013.

Address for reprints: Robert B. Xu, MBBS, Cardiothoracic Surgical Unit, Level 4, East Wing, Royal Adelaide Hospital, North Terrace, Adelaide, SA 5000, Australia (E-mail: robert.b.xu@gmail.com).

J Thorac Cardiovasc Surg 2013;145:e64-5 0022-5223/ $\$ 36.00$

Crown Copyright (C) 2013 Published by Elsevier Inc. on behalf of The American Association for Thoracic Surgery

http://dx.doi.org/10.1016/j.jtcvs.2013.02.029
At this time, a chyle leak was noted to be emanating from around the distal left subclavian anastomosis. This was controlled with pledgeted sutures (Ethicon, Somerville, NJ) and biological glue (Tisseel; Immuno AG, Vienna, Austria).

After surgical correction, the chyle leak resolved with the drains removed on day 3 . The remainder of the admission was uneventful, and the patient was discharged on day 34 .

After discharge, the patient was noted to have a reaccumulation of fluid in his left pleural cavity noted on follow-up imaging at 1 year, likely due to a persistent chylothorax. This was compounded by a frequent irritating productive cough, prompting re-referral for cardiothoracic surgical opinion 4 years after his original operation.

The sputum was noted by the patient to be a milky liquid. Sputum samples were submitted for pathologic testing, which although diluted nevertheless displayed a cholesterol level less than $0.5 \mathrm{mmol} / \mathrm{L}$, triglyceride level of $1.1 \mathrm{mmol} / \mathrm{L}$, and cholesterol to triglyceride ratio greater than 2.2, suggestive of chyle; pleural fluid also was collected (Figure 1), with a triglyceride level of $11.0 \mathrm{mmol} / \mathrm{L}$. Confirmatory chylomicron testing was not available through our pathology service. A nuclear lymphoscintigram also was performed, but because the chylothorax was a slow leak, there was no evidence of tracer uptake into the thoracic cavity on the limited duration of the scan. The diagnosis was a chylous pleural effusion complicated by a mediastinal-bronchial communication. The patient proceeded to right videoassisted thoracoscopy and successful ligation of the thoracic duct with ligating clips (Ethicon, Somerville, NJ) (Figure 2).

\section{RESULTS}

At 1-year follow-up, the patient was well with no reaccumulation of pleural fluid on imaging or recurrence of productive cough.

Chyloptysis is a rare condition that has been reported to occur spontaneously on a background of mediastinal lymphatic disorders, including lymphangioleiomyomatosis and thoracic lympangiectasis. ${ }^{2}$ However, iatrogenic injury also can be a cause, as in this case in which injury to the thoracic duct leading to chylous pleural effusion with coexisting mediastinal-bronchial fistula facilitates chyloptysis, one of the accepted mechanisms. ${ }^{3}$ Because the thoracic duct has a highly variable course, it is prone to injury, especially in esophageal or aortic surgery. 


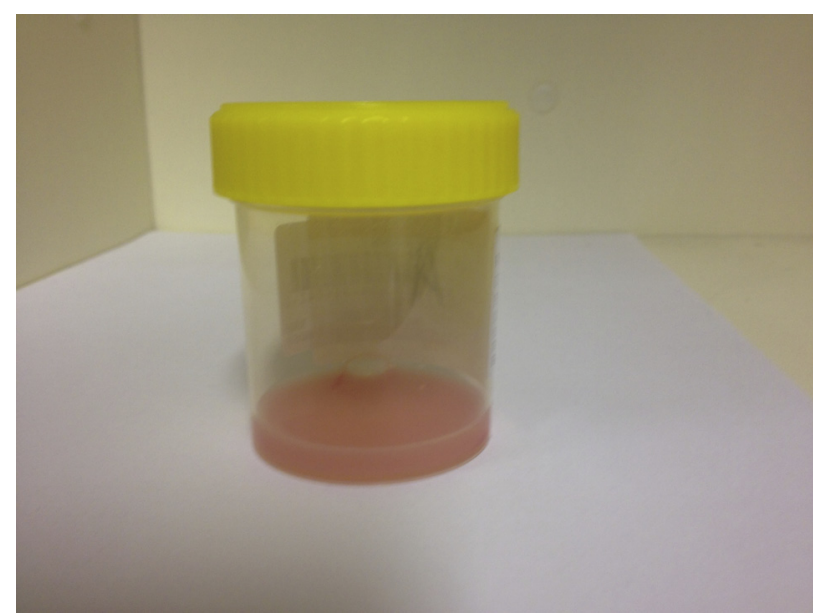

FIGURE 1. Chylous pleural fluid sample.

Symptoms will include expectoration of milky-white, foul-tasting sputum. However, the degree of production will be variable and not necessarily postprandial or linked with fatty food consumption. Lymphangiograms can aid in the diagnosis, although this is dependent on the speed of accumulation of the chyle leak. Where it is not available, radionuclide lymphoscintigraphy, normally reserved for imaging of malignant disease or lymphedema of the extremities, also can be used to visualize abnormalities of the thoracic duct. ${ }^{4}$

\section{CONCLUSIONS}

Iatrogenic injury to the thoracic duct is a not an uncommon consequence of thoracic cavity surgery. We present a case of such an injury after distal aortic arch repair, with persistent chylothorax and chyloptysis as a consequence.

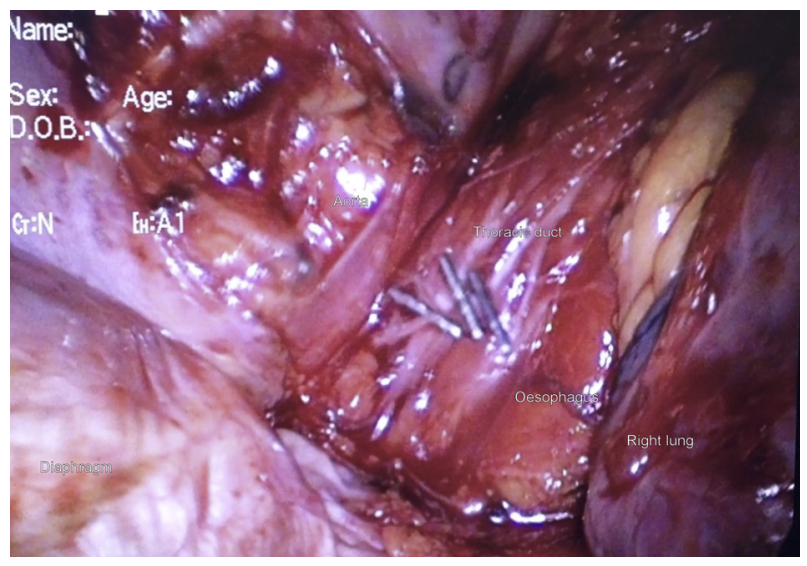

FIGURE 2. Thoracic duct ligation at video-assisted thoracic surgery.

Although the preference of the original treating surgeon was to attempt surgical correction via redo thoracotomy, in this case right-assisted video-assisted thoracoscopy duct ligation was used as a successful conclusive treatment modality. Because video-assisted thoracic surgery has a relatively low morbidity and cost, earlier use of this approach is supported by the literature. ${ }^{5}$

\section{References}

1. Staats BA, Ellefson RD, Budahn LL, Dines DE, Prakash UB, Offord K. The lipoprotein profile of chylous and nonchylous pleural effusions. Mayo Clinc Proc. 1980;55:700-4.

2. Lim KG, Rosenow EC, Staats B, Couture C, Morgenthaler TI. Chyloptysis in adults. Chest. 2004;125:336-40.

3. Tregunna R, Belcher E, Cane P. An unusual case of chyloptysis. J Thorac Cardiovasc Surg. 2011;142:e2-3.

4. Baulieu F, Baulieu J, Mesny J, Ducouret N, Benhamou A. Visualization of the thoracic duct by lymphoscintigraphy. Eur J Nucl Med. 1987;13:264-5.

5. Fahimi H, Casselman FP, Mariani MA, van Boven WJ, Knaepen PJ. Current management of postoperative chylothorax. Ann Thorac Surg. 2001;71:448-51.

\title{
Lung transplant in Jehovah's Witness patient
}

\author{
Francisco Cerezo Madueño, MD, Elisabet Arango Tomás, MD, and Ángel Salvatierra Velázquez, MD, \\ Córdoba, Spain
}

\footnotetext{
From the Thoracic Surgery and Lung Transplantation Unit, University Hospital Reina Sofía, Córdoba, Spain.

Disclosures: Authors have nothing to disclose with regard to commercial support.

Received for publication Dec 4, 2012; revisions received Jan 31, 2013; accepted for publication Feb 14, 2013; available ahead of print March 13, 2013.

Address for reprints: Elisabet Arango Tomás, MD, Division of Thoracic Surgery and Lung Transplantation, Reina Sofía University Hospital, Avda Menéndez Pidal s/n 14004-Córdoba, Spain (E-mail: eli_piano@ hotmail.com).

J Thorac Cardiovasc Surg 2013;145:e65-7

$0022-5223 / \$ 36.00$

Copyright (c) 2013 by The American Association for Thoracic Surgery

http://dx.doi.org/10.1016/j.jtcvs.2013.02.043
}

Studying transplant candidates can be difficult, especially if the patient states that he or she cannot accept homologous blood products, such as Jehovah's Witnesses. This has been discussed in the medical literature ${ }^{1}$; however, there are only 2 documented cases of lung transplantation (LT). ${ }^{2,3}$ We present the first right single $\mathrm{LT}$ for emphysema-type chronic obstructive pulmonary disease (COPD) in a man who is a Jehovah's Witness. 